\title{
Photochemically induced changes in bioavailable carbon and nitrogen pools in a boreal watershed
}

\author{
Stefan Bertilsson ${ }^{1}$, Ramunas Stepanauskas ${ }^{2}$, Rocio Cuadros-Hansson ${ }^{3}$, \\ Wilhelm Granéli ${ }^{2}$, Johan Wikner ${ }^{3}$, Lars Tranvik ${ }^{4, *}$ \\ ${ }^{1}$ Dept. of Water and Environmental Studies, Linköping University, 58183 Linköping, Sweden \\ ${ }^{2}$ Dept. of Ecology, Limnology, Lund University, 22362 Lund, Sweden \\ ${ }^{3}$ Umeå Marine Science Center, Box 10124, 90010 Umeå, Sweden \\ ${ }^{4}$ Dept. of Limnology, Uppsala University, Norbyvägen 20, 75236 Uppsala, Sweden
}

\begin{abstract}
In several recent studies, a net stimulation of bacterial growth has been demonstrated after exposing humic surface waters to solar radiation or artificial ultraviolet radiation. This stimulation has been attributed to a photochemical release of bioavailable carbon or nitrogen compounds (ammonium). In a synoptic experiment, we exposed $0.2 \mu \mathrm{m}$ filtered water from 12 different habitats in a river system, dominated by allochthonous carbon input, to mild artificial UV radiation. A significant photochemical release of carboxylic acids of low molecular weight occurred. Furthermore, the exposure increased carbon-limited bacterial yield on average by a factor of 1.7. No photochemical production of free ammonium could be detected, which was in accordance with the lack of effects of radiation on bacterial growth yield under nitrogen-limited conditions. We conclude that, in boreal systems dominated by allochthonous carbon input, photochemical production of bioavailable carbon rather than nitrogen compounds is likely to positively influence the total substrate pool available for bacterial utilization.
\end{abstract}

KEY WORDS: UV radiation $\cdot$ DOC $\cdot$ DON $\cdot$ Bacterial bioassays $\cdot$ Carboxylic acids $\cdot$ Ammonium

\section{INTRODUCTION}

Heterotrophic bacteria form an important link between dissolved organic matter (DOM) as well as particulate organic matter and higher trophic levels in aquatic ecosystems (Fenchel \& Jørgensen 1977). These bacteria obtain both energy and nutrients by utilization of DOM. The growth efficiency, i.e. the fraction of metabolized substrate-carbon that is incorporated into bacterial biomass, is a function of the quality of the DOM, the energy demands associated with the utilization, and extrinsic factors such as temperature, availability of nutrients and effective electron acceptors (e.g. Vallino et al. 1996, del Giorgio et al. 1997, Reche et al. 1999).

The main fraction of bulk DOM in boreal surface waters consists of polymeric molecules of poorly

\footnotetext{
- Addressee for correspondence.

E-mail: lars.tranvik@limno.uu.se
}

defined structure. These organic compounds have generally been considered to be poor substrates since they must be degraded to substances of low molecular weight (LMW) prior to uptake and utilization (Azam \& Cho 1987, Lancelot et al. 1989). In addition to strictly biological degradation of these high molecular weight (HMW) compounds (Geller 1986, Moran \& Hodson 1990, Tranvik 1990, Münster et al. 1992), solar radiation has also been shown to render the total organic carbon pool in humic waters more available for bacterial utilization (Geller 1986, Lindell et al. 1995). This is in agreement with recent observations of a substantial, photochemically induced degradation of heterogeneous HMW DOM into structurally defined LMW organic compounds which are then used as bacterial substrates (Kieber et al. 1990, Wetzel et al. 1995, Bertilsson \& Allard 1996, Bertilsson \& Tranvik 1998). In addition to these reports of photochemical alterations in the quality of dissolved organic carbon (DOC), Bushaw et al. (1996) demonstrated a significant photo- 

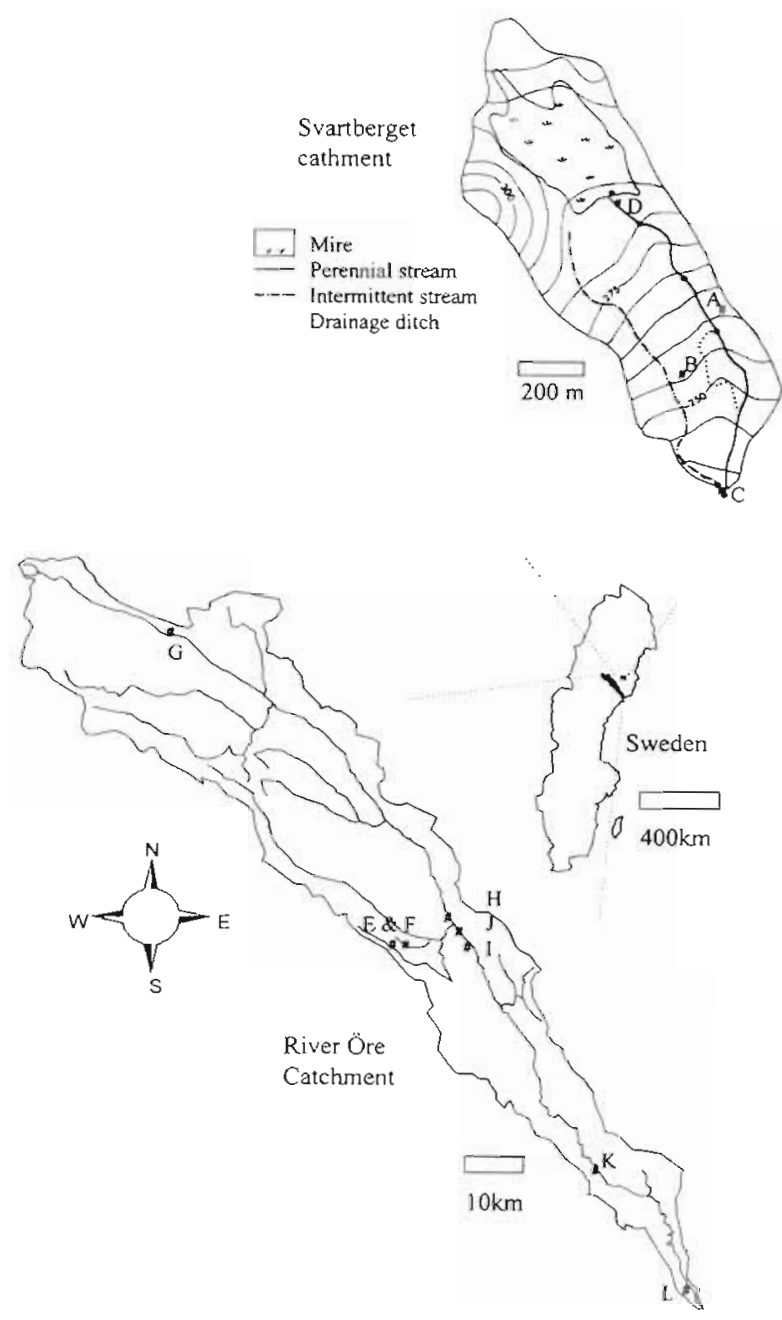

Fig. 1. Map of the River Öre and Svartberget catchments with sampling Stns A to L marked according to Table 1

chemical production of free ammonium in several North American surface waters with high humic content, as well as in aqueous solutions of isolated humic substances. In parallel, they also observed a photochemically induced increase in bacterial protein synthesis in both carbon-and nitrogen-limited bioassay experiments, using an aqueous solution of an isolated fulvic acid as substrate. They suggested that the photochemical ammonification makes humic nitrogen more available for subsequent bacterial utilization, and that this could be an important regulator of dissolved organic nitrogen (DON) dynamics.

It is still uncertain whether these photochemical and combined photochemical-microbial reactions of terrigenous DOM are ubiquitous in aquatic ecosystems. Furthermore, any use of isolated humic substances in bioassay experiments only addresses photochemical alteration of a limited fraction of the total DOM pool, obscuring the interpretation of net effects of solar radi- ation on total substrate availability in natural systems. Hence, we performed a synoptic study in natural water from a boreal watershed with sampling sites ranging from groundwater and first order streams to a nearestuarine river site.

We studied the influence of UV irradiation on the production of ammonium, dissolved inorganic carbon (DIC), and some previously identified, quantitatively important organic photoproducts (oxalic, formic, malonic and acetic acid). Furthermore, we assessed the influence of the photochemically altered pool of total available substrates on bacterial growth under carbonor nitrogen-limited conditions in order to study the net effect of irradiation on both carbon and nitrogen bioavailability.

\section{MATERIAL AND METHODS}

Sampling and experimental design. Surface water was collected during August 1997. We sampled 8 sites within the River Öre catchment in northern Sweden. The catchment is $2940 \mathrm{~km}^{2}$, sparsely populated and dominated by productive forestland $(65 \%$; mostly spruce and pine) and mires (20\%). There is no major influence from anthropogenic point sources. In addition, 2 groundwater and 2 streamwater sites were sampled in the closely situated Svartberget catchment area, also dominated by mires and coniferous forests. The catchments are described in more detail in Ivarsson \& Jansson (1994) and Bishop (1991) Water sampling sites were selected to represent a variety of qualitatively different humic waters, ranging from groundand headwaters to lakes, rivers and the near-estuarine environment (Fig 1). All waters had low conductivity (20 to $45 \mu \mathrm{S} \mathrm{cm}^{-1}$ ) and low to neutral $\mathrm{pH}$ (5.1 to 7.1). In situ temperature varied from 6 to $18^{\circ} \mathrm{C}$.

From each of the 12 sampling stations, 4 replicates of at least $10 \mathrm{l}$ each were collected in acid-washed polyethylene or polypropylene bottles. Samples were immediately transported to the laboratory and were separately filtered through a $25 \mu \mathrm{m}$ pore size glassfiber filter (Gamma-12, Whatman) and a $0.2 \mu \mathrm{m}$ pore size Supor filter (SuporCap 100, Gelman Sciences) previously flushed with Milli-Q grade water. Preliminary tests showed no significant leakage of bioavailable carbon or nitrogen from the filters (results not shown). Two 21 aliquots from each sterile filtered replicate water sample were poured into acid-washed, UV. transparent polypropylene plastic bags (Fig. 2) which were then thermally sealed. One of these duplicate bags was kept dark in a flow-through aquarium at $15^{\circ} \mathrm{C}$, while the other one was kept under similar conditions, but exposed to artificial UV radiation (UVA340, Q-Panel Co., USA) for $12 \mathrm{~h}$, receiving $2.1 \mathrm{~W} \mathrm{~m}^{-2}$ of 
UV-B (280 to $320 \mathrm{~nm}$ ), $20 \mathrm{~W} \mathrm{~m}^{-2}$ of UV-A ( 320 to $400 \mathrm{~nm}$ ), and $5 \mathrm{~W} \mathrm{~m}^{-2}$ of PAR (400 to $750 \mathrm{~nm}$ ) at the surface. The UV radiation emitted from the lamps is of similar intensity as the solar radiation on a clear summer day in southern Sweden but with an overrepresentation of radiation at lower wavelengths, particularly in the UV-A range (Fig. 2). PAR, on the other hand, constitutes less than $2 \%$ of the radiation emitted by the sun. The irradiance was measured with an IL-1400 A radiometer (International Light), equipped with broad band sensors for UV-B, UV-A and PAR. The broad band sensors were calibrated using an Optronics Model 752 spectroradiometer. The average radiation path length of the bags was approximately $4 \mathrm{~cm}$ and the distance to the lamps was $30 \mathrm{~cm}$. Parallel to the irradiation of water samples in bags, similar irradiations of the filter-sterilized water samples were also performed in $50 \mathrm{ml}$ acid-washed quartz tubes with gas-tight ground stoppers for measurements of photochemical production of DIC (Granéli et al. 1996) as well as LMW carboxylic acids and ammonium. Irradiation path lengths and transmission curves were similar for tubes and bags (Fig. 2).

Immediately after the irradiation, a site-specific bacterial inoculum, prepared by filtering a water sample from each site through a precombusted Whatman GF/F filter, was added to the irradiated bags and the dark controls to a final inoculum concentration of $10 \%$. After mixing, each inoculated sample was split into 2 batches and 2 types of cultures were prepared, one under nitrogen-limited conditions (1.2 $\mathrm{mM} \mathrm{PO}_{4}{ }^{3-}$ and $1.25 \mathrm{mM}$ glucose added), and one under carbon-limited conditions $\left(1.2 \mathrm{mM} \mathrm{PO}_{4}{ }^{3-}\right.$ and $300 \mu \mathrm{M} \mathrm{NO}_{3}{ }^{-}$). The high $\mathrm{PO}_{4}{ }^{3-}$ concentration chosen was to account for the potential binding to abundant $\mathrm{Fe}^{3+}$, other cations and humic substances in the water. These dilution cultures were then incubated in the dark for a total of $8 \mathrm{~d}$, with the aim to measure the bioavailable fraction of the total DOC and the potential growth of bacteria in various waters (Tranvik 1998). The temperature during the incubation ranged from 15.8 to $16.7^{\circ} \mathrm{C}$. The bacterial growth yield was determined as the bacterial biomass in the plateau phase, appearing after the exponential growth phase in the cultures. The plateau phase was in most cases entered between 6 and $8 \mathrm{~d}$ after the initiation of the cultures. In a few cases where declines of bacteria occurred towards the end of the plateau phase, the maximum bacterial abundance was used to calculate the yield. This decline could be due to viral infection and subsequent lysis or bacterivore grazing. Indeed, at the end of the incubations, we observed a small number of flagel-

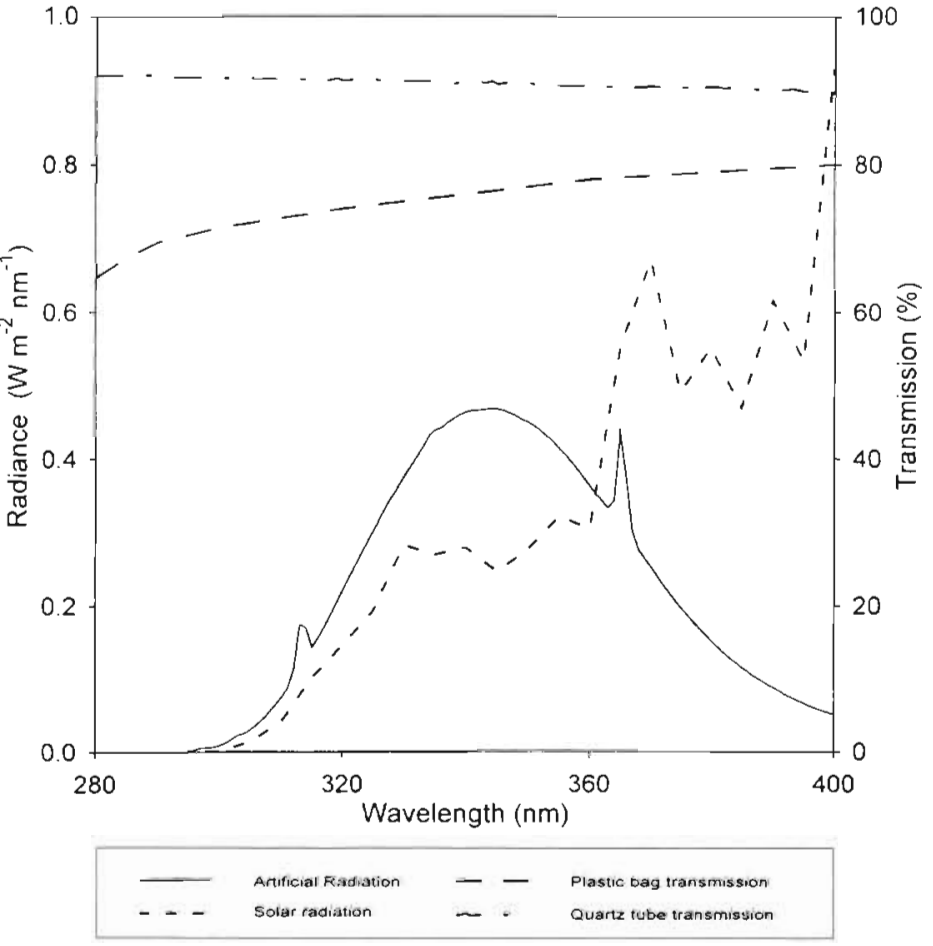

Fig. 2. Spectral characteristics of the artificial radiation source $(Q-$ panel UV-A340) in comparison to summer solstice natural solar radiation, as well as transmission curves for the plastic bags and quartz tubes used in the experiment

lates in a few of the cultures. Microscopic monitoring of autofluorescent picocyanobacteria, excited at wavelengths between 450 and $565 \mathrm{~nm}$ (Andersson et al. 1996), did not indicate any presence of such cells in the cultures.

Water for an initial chemical characterization (DOC, fluorescence, absorbance, XAD 8/4 fractionation, $\mathrm{pH}$, total nitrogen, nitrate, nitrite, and ammonium concentrations) was sampled and analyzed immediately after filtration in 2 replicates from each sampling site. DIC concentration was measured in the quartz tubes immediately after the irradiation (Granéli et al. 1996). Subsequently, aliquots for ammonium and LMW carboxylic acid analyses were sampled and frozen $\left(-20^{\circ} \mathrm{C}\right)$ until analysis. Bacterial samples were taken from the inoculated cultures each day during the $8 \mathrm{~d}$ incubation, and were preserved by adding $0.2 \mu \mathrm{m}$ filtered sodium tetraborate-buffered formaldehyde to a final concentration of $2 \%$. These samples were kept at $4^{\circ} \mathrm{C}$ until analysis. In addition, samples for DOC analyses were also taken at the end of the inoculated cultures for estimating the fraction of total bioavailable DOC.

Bacterial analyses. Bacterial cell numbers were measured flow-cytometrically (del Giorgio et al. 1996). Syto 13 stain (50 $\mu \mathrm{M}$, Molecular Probes) and Fluoresbrite Carboxy YG microspheres $(1.58 \mu \mathrm{m}$ diameter, 
between 3 and $9 \times 10^{5} \mathrm{ml}^{-1}$, Polysciences) were added to $1 \mathrm{ml}$ subsamples and were analysed with either a Becton Dickinson FACSort (nitrogen-limited cultures) or a FACSCalibur (carbon-limited cultures) flow cytometer at a low sample flow-rate (about $12 \mu \mathrm{l}$ $\min ^{-1}$ ). The cytometers were controlled with the CellQuest 1.2 software. Bacterial cells and microspheres were separated in a log-log scattergram of green fluorescence intensity (FL1) and side scattering (SSC). Voltages for these parameters were set to 560 and 400 , respectively, Samples were run for 1 min or until a minimum of 5000 cells was counted. Bacterial cell concentrations in the samples were calculated using microspheres as an internal standard. The density of the microspheres in a stock solution was analyzed by epifluorescence microscopy on a weekly basis. Selected samples were also counted microscopically after staining with DAPI (Porter \& Feig 1980). At least 20 fields or 200 cells were counted. Flow cytometric counts did not differ significantly from microscopic counts (paired $t$-test, $\mathrm{df}=9, \mathrm{p}>0.1$ ), and had a high subsample reproducability with a coefficient of variation not exceeding $5 \%$.

Cell size was determined by image-analyzed fluorescence microscopy of acridine-orange-stained cells (Hobbie et al. 1977), using a cooled, slow-scan chargecoupled device camera, CCD (C4742 Hamamatsu). An Axioplan microscope was used with a $100 \times$ Neofluar objective. Acquired images were calibrated in the camera controller and transmitted to a digital frame grabber program (IQBase ver. 1.20). A neural networkbased image analysis procedure was initiated from processing and analysis software (LabView ver. 2.0).

The length (l) and area (A) of 70 to 500 focused cells were recorded. Cell volumes $(V)$ were calculated according to the formula $V=4\left(\pi \mathrm{r}^{3} / 3+(\mathrm{I}-2 \mathrm{r}) \pi \mathrm{r}^{2}\right.$, which approximates the form of each cell by assuming it is a cylinder with hemispherical end caps. Bio-volumes were converted to bacterial carbon biomass by assuming that carbon comprised $50 \%$ of the bacterial dry weight and using a volume to dry weight relationship (Loferer-Krößbacher et al. 1998): $m_{\mathrm{b}}=435 \times V^{086}$, where $m_{\mathrm{b}}$ is the dry weight of the bacterial cell ( $\mathrm{fg}$ cell $\left.{ }^{-1}\right), V$ is the bacterial volume $\left(\mu \mathrm{m}^{3}\right)$, taking into account that the carbon density increases with decreasing cell volume (Simon \& Azam 1989).

Chemical analyses. $\mathrm{NH}_{4}, \mathrm{NO}_{2}, \mathrm{NO}_{3}$, and total nitrogen (Tot-N) in initial samples were analyzed with an autoanalyzer (Technicon TRAACS 800) according to methods described by Grasshoff et al. (1983). Fifty ml of the subsamples were transferred to acid-rinsed polypropylene test tubes and kept at $+4^{\circ} \mathrm{C}$ until further analysis (less than $24 \mathrm{~h}$ ). DON was determined by the difference between Tot- $\mathrm{N}$ in the $0.2 \mu \mathrm{m}$ fraction (cellulose acetate filter, Sartorius), and the sum of inorganic nitrogen. The detection limit for $\mathrm{NH}_{4}$ and $\mathrm{NO}_{3}$ was 0.07 , and $0.05 \mu \mathrm{M}$, respectively,

Water samples for DOC analysis were filtered trough $0.2 \mu \mathrm{m}$ Gelman Supor filters using sterile syringes and filterholders according to Zweifel et al. (1993), $7.5 \mathrm{ml}$ of filtered water was collected in $15 \mathrm{ml}$ polypropylene test tubes and was immediately acidified with $100 \mu \mathrm{l}$ of 1.2 $\mathrm{M} \mathrm{HCl}$ to remove inorganic carbon. The samples were stored cold $\left(+4^{\circ} \mathrm{C}\right)$ until analysis. The analysis was done within $24 \mathrm{~h}$. All material coming into contact with the samples was carefully rinsed with $1 \mathrm{M} \mathrm{HCl}$ and washed with uitra-pure water (Millipore Milli-Q). DOC was measured with the high temperature catalytic oxidation method (HTCO) using a Shimadzu TOC-5000 instrument, which has been subjected to international intercalibration (Peltzer et al. 1996). Samples of $150 \mu \mathrm{l}$ were injected in triplicate showing standard deviations of 0 to $2 \%$. Calculations of carbon concentrations were made from standard solutions of potassium hydrogen phthalate. The detection limit of the applied DOC protocol was $17 \mu \mathrm{M}$.

Absorbance at 250 and $365 \mathrm{~nm}$ was measured in a $1 \mathrm{~cm}$ quartz glass cuvette using a Shimadzu MPS-2000 spectrophotometer. Humic substance fluorescence was determined using a Perkin Elmer LS30 spectrofluorometer at $350 \mathrm{~nm}$ excitation and $450 \mathrm{~nm}$ emission wavelength. Fluorescence was determined twice for each subsample. $\mathrm{H}_{2} \mathrm{SO}_{4}(0.5 \mathrm{M})$ was used as a blank. Values were normalized to the fluorescence of quinine sulphate using standard solutions, with 1 quinine sulphate unit being equal to the fluorescence of a $1 \mathrm{\mu g} \mathrm{l}^{-1}$ solution in $0.5 \mathrm{M} \mathrm{H}_{2} \mathrm{SO}_{4}$.

Tandem isolation of XAD-8 and XAD-4 adsorbable compounds was performed to quantify the amount of humic (XAD-8) and moderately hydrophilic (XAD-4) acids in the different water samples (Malcolm \& MacCarthy 1992). Briefly, 7 to $800 \mathrm{ml}$ of filter-sterilized water was acidified to $\mathrm{pH} 1.9$ by $\mathrm{HCl}$ additions. Samples were applied to tandem-coupled columns (35 ml bed volume), containing XAD- 8 and XAD-4 resins, at a flow rate of about $4 \mathrm{ml} \mathrm{min}{ }^{-1}$. Adsorbed compounds were eluted with $0.1 \mathrm{M} \mathrm{NaOH}$ that was flushed through each column in the reversed direction and subsequently passed through a cation exchange resin in the $\mathrm{H}^{+}$form. DOC was measured in the initial, adsorbed, and unadsorbed fractions.

LMW carboxylic acids were analysed using a previously described capiliary ion electrophoresis method (Dahlén et al. 1996). Analytes were separated on a fused silica capillary using a $5 \mathrm{mM} \mathrm{1,2,4-benzene}$ tri-carboxylic acid buffer ( $\mathrm{pH} 7.9$ ) containing $0.5 \mathrm{mM}$ of an electroosmotic flow modifier (OFM-BT, Waters) and a separation voltage of $15 \mathrm{kV}$. Analytes were injected using electrokinetic preconcentration (45 s at $5 \mathrm{kV}$ ) and detection was by indirect UV absorption at 
$254 \mathrm{~nm}$. Molybdate was added to all samples as an internal standard, and identification and quantification of the analytes were achieved by carboxylic acid standard additions for every sampling station. The added concentrations covered the range of observed concentrations in the experiment. Standard curves for concentration estimates were obtained by linear regressions $\left(r^{2}>0.99\right.$ for all acids and water samples, $\mathrm{n}=4)$.

DIC was analysed by direct injection of sample from incubated quartz-tubes into a Shimadzu TOC-5000 total carbon analyzer (Granéli et al. 1996). At least 3 injections were made resulting in a coefficient of variation of less than $2 \%$. Standard procedures were followed for measurements of ammonium (Chaney \& Marbach 1962).

The effects of radiation treatment (non-irradiated, UV-A exposed) on individual biological and chemical response parameters were evaluated by 2-way ANOVA, with sampling station as the second factor. Prior to analysis, data were log-transformed.

\section{RESULTS}

Concentration of DOC in the sampled waters was high, from 600 to $2192 \mu \mathrm{M}$, except for Stn A groundwater which had only $200 \mu \mathrm{M}$ DOC (Table 1). All waters were characterized by a high content of humic substances (between 49 and $87 \%$ of total DOC was adsorbed on XAD-8). The content of moderately hydrophilic organic acids (XAD-4 adsorbable DOC) was typically low (below 10\%; Table 1). The DOC/DON ratio in the River Öre system (Stns $E$ to L) varied little with an average of $46 \pm 3$. The ratio was significantly higher in Svartberget streams (58 and 59,
Stns C to D), while it was extremely low (4.3) in the sandy groundwater (Stn A) and intermediate in the more humic groundwater (Stn B) (Table 1). DON was the dominant nitrogen form comprising 66 to $99 \%$ of the total dissolved $\mathrm{N}$ in the sampled waters.

In bacterial regrowth cultures, the maximum number of cells reached under nitrogen limitation was not significantly affected by the irradiation (ANOVA, p > 0.05, Fig. 3A). This result is in agreement with the absence of photochemical production of ammonium (ANOVA, $p>0.05$, Table 2 ). Contrasting results were obtained under C-limited conditions, where DOM irradiation significantly enhanced bacterial growth yield (ANOVA, $p<0.001$ ), on average by a factor of 1.7 (Fig. 3B).

The average volume of individual bacterial cells in $N$-limited cultures $\left(0.138 \pm 0.038 \mu^{3}\right)$ was somewhat higher than in C-limited cultures $\left(0.104 \pm 0.017 \mu^{3}\right.$, ANOVA, $p<0.001$ ) and differed among the sampling stations $(p<0.001)$. However, there were no significant differences in average cell volume between the dark and the irradiated samples, neither in $\mathrm{N}$ - nor in C-limited cultures $(p>0.05)$. Since the image analysis showed that bacterial cell sizes were similar in dark and irradiated cultures, we assume that bioassay results derived from the more analytically robust flowcytometric cell counts adequately reflect the effect of irradiation on bacterial biomass development in the cultures.

The decrease in DOC in carbon-limited bacterial incubations, measured by $\mathrm{HTCO}$, ranged from 31 to $227 \mu \mathrm{M} \mathrm{C} \mathrm{l}^{-1}$ for the different stations (Stns $\mathrm{A}$ to $\mathrm{L}$ ) and treatments (irradiated/non-jrradiated). The decrease corresponded to between 4.4 and $27 \%$ of the initial DOC for all the different stations except for the sandy groundwater station (Stn A), where this fraction was

Table 1. Characterization of dissolved organic carbon (DOC) and nitrogen (DON) in the sterile-filtered water. Presented values are means of 2 replicates or single measurements (XAD-8 and XAD-4 analyses). na: not analyzed. Fluor: fluorescence of DOM in quinine sulphate units (QSU), A: absorbance at indicated wavelength, XAD-8/-4: fraction of total DOC being adsorbed to respective resin, and DIN: dissolved inorganic nitrogen

\begin{tabular}{|c|c|c|c|c|c|c|c|c|c|c|}
\hline \multicolumn{2}{|c|}{ Sampling station } & \multirow{2}{*}{$\begin{array}{c}\text { DOC } \\
\mu \mathrm{M} \\
200\end{array}$} & \multirow{2}{*}{$\begin{array}{c}\text { DON } \\
\mu \mathrm{M} \\
\frac{47}{4}\end{array}$} & \multirow{2}{*}{$\begin{array}{r}\text { DIN } \\
\mu \mathrm{M}\end{array}$} & \multirow{2}{*}{$\begin{array}{c}\text { DOC/ } \\
\text { DON } \\
4.3\end{array}$} & \multirow{2}{*}{$\begin{array}{c}\text { XAD- } 8 \\
\% \text { of DOC } \\
87\end{array}$} & \multirow{2}{*}{$\begin{array}{l}\text { XAD-4 } \\
\% \text { of DOC } \\
4\end{array}$} & \multirow{2}{*}{$\begin{array}{c}\text { Fluor/DOC } \\
\text { QSU/mM C } \\
60\end{array}$} & \multirow{2}{*}{$\begin{array}{c}\begin{array}{c}\text { A365/DOC } \\
\mu \mathrm{M} \mathrm{C} \mathrm{C}^{-1} \mathrm{~cm}^{-1}\end{array} \\
5\end{array}$} & \multirow{2}{*}{$\begin{array}{c}A 250 / 365 \\
9.0\end{array}$} \\
\hline A & Groundwater 1 & & & & & & & & & \\
\hline B & Groundwater 2 & 850 & 19 & 3.0 & 45 & na & na & 529 & 53 & 5.8 \\
\hline $\mathrm{C}$ & Forest stream & 1308 & 22 & 3.4 & 59 & 67 & 4 & 380 & 155 & 4.0 \\
\hline $\mathrm{D}$ & Mire stream & 2192 & 38 & 19.4 & 58 & na & na & 338 & 128 & 4.1 \\
\hline $\mathrm{E}$ & Björntjärn inflow & 1558 & 33 & 2.2 & 47 & 80 & 5 & 401 & 161 & 4.0 \\
\hline $\mathrm{F}$ & Björntjärn outflow & 1971 & 40 & 1.8 & 50 & 66 & 4 & 457 & 176 & 4.1 \\
\hline G & Öravan & 600 & 14 & 0.5 & 42 & 63 & 7 & 475 & 73 & 5.4 \\
\hline $\mathrm{H}$ & Örträsk inflow & 683 & 16 & 0.5 & 42 & 51 & 9 & 574 & 101 & 5.1 \\
\hline I & Örträst outflow & 1154 & 24 & 1.5 & 49 & 62 & 5 & 585 & 117 & 4.8 \\
\hline $\mathrm{J}$ & Örträsk hypol. & 992 & 21 & 4.0 & 47 & 62 & 4 & 598 & 121 & 4.7 \\
\hline $\mathrm{K}$ & Tallbergsbron & 954 & 20 & 1.4 & 47 & 49 & 4 & 570 & 116 & 4.8 \\
\hline $\mathrm{L}$ & Strömsör & 783 & 18 & 0.8 & 44 & 56 & 6 & 609 & 133 & 4.7 \\
\hline
\end{tabular}




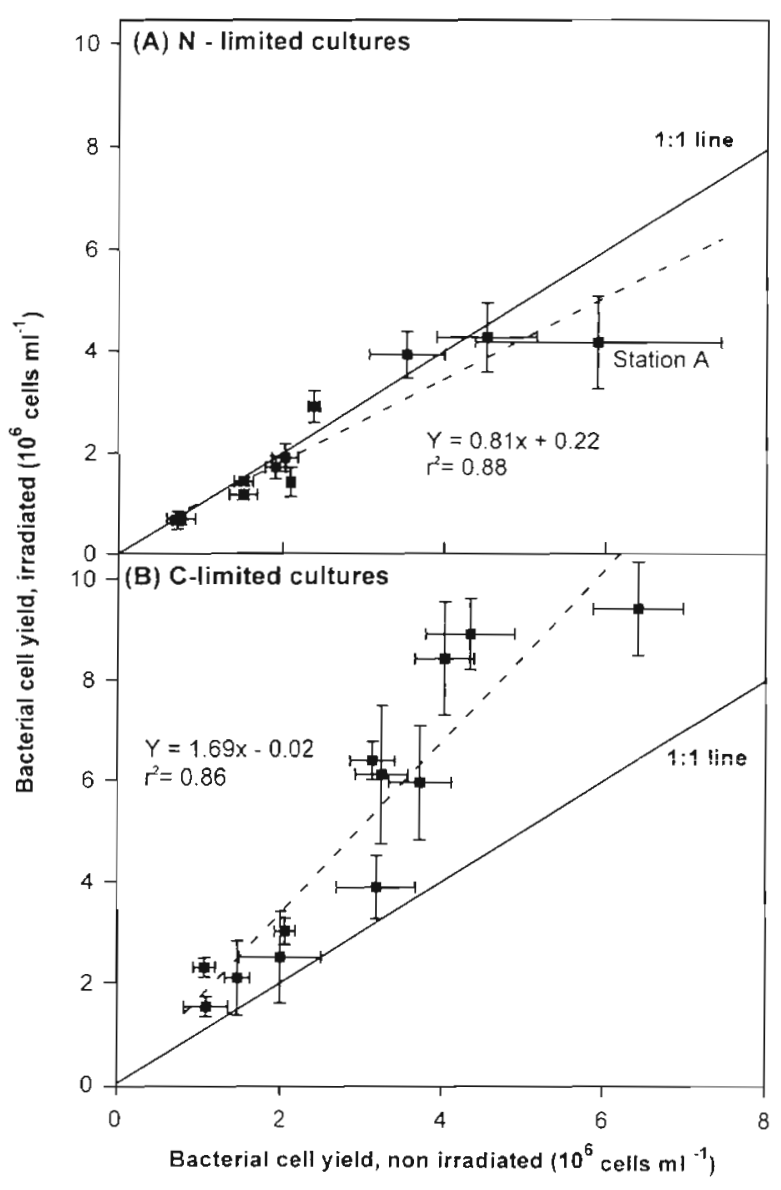

Fig. 3. Correlation between maximal bacterial cell yields in irradiated and non-irradiated water in dilution cultures under (A) nitrogen and (B) carbon limitation. Values are means $(\mathrm{n}=4)$ and error bars represent standard deviations. Dashed lines indicate the linear regressions $(n=12)$, while the solid lines indicate equal cell yield in irradiated and non-irradiated cultures

significantly higher (up to $60 \%$ ). Assuming that this decrease corresponds to the bacterial utilization of DOC, it gives an average growth efficiency of $7.4 \%$ (range 2.5 to $18.5 \%$ ). There were no significant differences between irradiated and dark samples (paired $t$ test, $\mathrm{p}>0.05$ ).

The photochemically induced increase in bacterial growth under carbon-limited conditions was preceded by a photochemically induced increase in the 4 analyzed LMW carboxylic acids (ANOVA, p < 0.001 , Fig. 4). The concentration of each individual carboxylic acid (oxalic, malonic, formic, and acetic acids) increased in all waters upon irradiation, with formic acid being the dominant photoproduct in most cases (Table 2). However, there was no significant correlation between the magnitude of photochemical enhancement of bacterial yield and carboxylic acid production (Table 3 ).

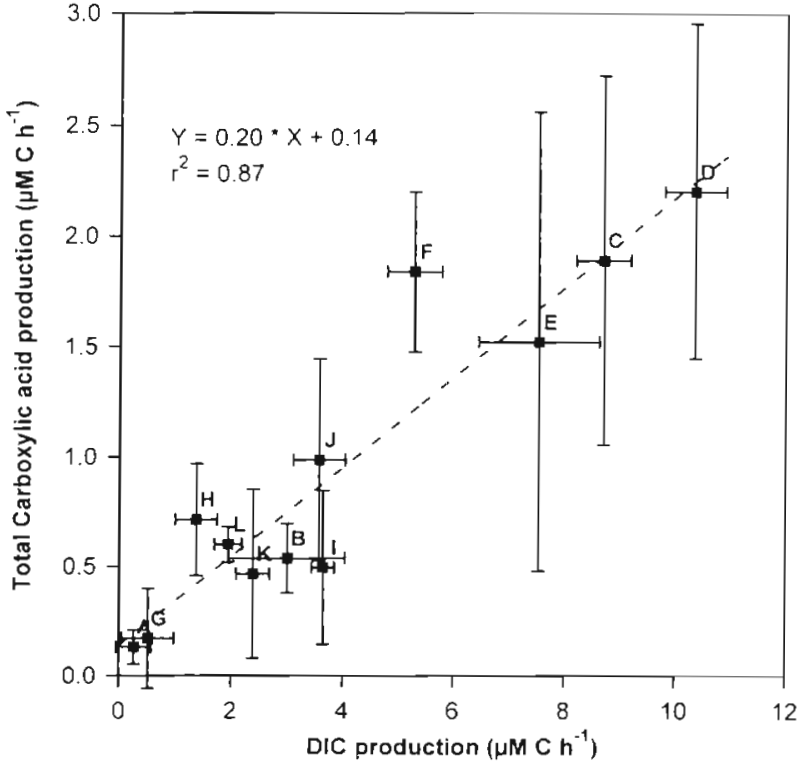

Fig. 4. Correlation between rates of photochemically induced formation of dissolved inorganic carbon (DIC) and carboxylic acid carbon (sum of oxalic, malonic, formic, and acetic acid carbon). Values are means $(n=4)$. The linear regression $(n=$ 12 ) is included in the graph and error bars indicate standard deviation for each station (Stns $\mathrm{A}$ to $\mathrm{L}$ according to Table 1 )

Parallel to the photochemical production of LMW organic acids, the total organic carbon pool decreased through the photooxidative production of DIC (ANOVA, $p<0.0001$ ), removing potential organic substrates from the system (Fig. 4). The rate of DIC formation was on average 5 times more rapid than the formation of the combined carbon in the 4 measured carboxylic acids. The photoproduction of LMW carboxylic acids and DIC were linearly correlated. The LMW carboxylic acid production was also positively correlated to the initial DOC concentration and to a minor degree with absorption and fluorescence (Table 3).

\section{DISCUSSION}

\section{DOC versus DON photoreactivity}

The UV irradiation had contrasting effects on DOC and nitrogen. Bacterial bioassays showed that the pool of bioavailable DOC increased after the irradiation while nitrogen did not (Fig 3A,B). In agreement with these findings, substantial photoproduction of LMW organic acids was observed while there was no measurable formation of ammonium in our experiments (Table 2). These results are contradictory to the recently suggested importance of a photochemical net- 
Table 2. Ammonium and carboxylic acid carbon (CA-C) concentrations in irradiated surface watersand dark controls from Stns A to $L$. Presented values are means $(n=4)$ and standard deviations are in parentheses. nd: not detected

\begin{tabular}{|c|c|c|c|c|c|c|}
\hline Stn & Treatment & $\begin{array}{r}\text { Oxalic acid } \\
\text { ( } \mu \mathrm{M} \text { CA-C) }\end{array}$ & $\begin{array}{c}\text { Malonic acid } \\
(\mu \mathrm{M} C \mathrm{~A}-\mathrm{C})\end{array}$ & $\begin{array}{l}\text { Formic acid } \\
(\mu \mathrm{M} C A-C)\end{array}$ & $\begin{array}{l}\text { Acetic acid } \\
\text { ( } \mu \mathrm{M} \text { CA-C) }\end{array}$ & $\begin{array}{l}\mathrm{NH}_{4}{ }^{+} \\
(\mu \mathrm{M})\end{array}$ \\
\hline A & $\begin{array}{l}\text { Non irrad. } \\
\text { Irradiated }\end{array}$ & $\begin{array}{l}0.19(0.02) \\
0.45(0.54)\end{array}$ & $\begin{array}{l}\text { nd } \\
\text { nd }\end{array}$ & $\begin{array}{l}0.43(0.10) \\
0.77(0.22)\end{array}$ & $\begin{array}{l}0.87(0.41) \\
1.84(0.25)\end{array}$ & $\begin{array}{l}1.07(0.15) \\
0.97(0.21)\end{array}$ \\
\hline B & $\begin{array}{l}\text { Non irrad. } \\
\text { Irradiated }\end{array}$ & $\begin{array}{l}0.34(0.10) \\
1.54(0.20)\end{array}$ & $\begin{array}{c}\text { nd } \\
2.07(0.68)\end{array}$ & $\begin{array}{l}0.27(0.09) \\
2.47(0.67)\end{array}$ & $\begin{array}{l}0.37(0.11) \\
1.34(0.38)\end{array}$ & $\begin{array}{l}3.29(0.29) \\
3.19(0.94)\end{array}$ \\
\hline C & $\begin{array}{l}\text { Non irrad. } \\
\text { Irradiated }\end{array}$ & $\begin{array}{l}1.43(0.48) \\
2.07(0.81)\end{array}$ & $\begin{array}{l}0.31(0.12) \\
5.46(2.41)\end{array}$ & $\begin{array}{r}0.75(0.20) \\
10.59(3.91)\end{array}$ & $\begin{array}{l}2.60(0.73) \\
9.62(3.00)\end{array}$ & $\begin{array}{l}1.82(0.79) \\
1.76(0.83)\end{array}$ \\
\hline $\mathrm{D}$ & $\begin{array}{l}\text { Non irrad. } \\
\text { Irradiated }\end{array}$ & $\begin{array}{l}2.57(0.20) \\
3.03(0.63)\end{array}$ & $\begin{array}{l}0.38(0.03) \\
7.58(2.20)\end{array}$ & $\begin{array}{r}1.15(0.52) \\
13.02(3.43)\end{array}$ & $\begin{array}{l}1.19(0.43) \\
8.05(2.97)\end{array}$ & $\begin{array}{l}12.58(0.94) \\
10.86(0.84)\end{array}$ \\
\hline $\mathrm{E}$ & $\begin{array}{l}\text { Non irrad. } \\
\text { Irradiated }\end{array}$ & $\begin{array}{l}1.19(0.48) \\
2.06(0.85)\end{array}$ & $\begin{array}{l}0.26(0.07) \\
4.66(2.53)\end{array}$ & $\begin{array}{r}1.11(0.82) \\
10.11(5.46)\end{array}$ & $\begin{array}{l}2.35(0.40) \\
6.32(3.67)\end{array}$ & $\begin{array}{l}1.48(0.55) \\
2.18(0.40)\end{array}$ \\
\hline $\mathrm{F}$ & $\begin{array}{l}\text { Non irrad. } \\
\text { Irradiated }\end{array}$ & $\begin{array}{l}1.03(0.40) \\
3.28(0.34)\end{array}$ & $\begin{array}{l}0.33(0.14) \\
5.77(1.00)\end{array}$ & $\begin{array}{r}1.85(0.97) \\
10.44(1.65)\end{array}$ & $\begin{array}{l}2.21(1.54) \\
7.98(1.66)\end{array}$ & $\begin{array}{l}4.04(2.55) \\
0.89(0.32)\end{array}$ \\
\hline G & $\begin{array}{l}\text { Non irrad. } \\
\text { Irradiated }\end{array}$ & $\begin{array}{l}0.19(0.14) \\
0.63(0.33)\end{array}$ & $\begin{array}{c}\text { nd } \\
0.47(0.23)\end{array}$ & $\begin{array}{c}0.54(0.39) \\
1.14(0.68)\end{array}$ & $\begin{array}{l}1.48(1.11) \\
2.01(1.01)\end{array}$ & $\begin{array}{l}1.27(0.39) \\
2.08(1.76)\end{array}$ \\
\hline $\mathrm{H}$ & $\begin{array}{l}\text { Non irrad. } \\
\text { Irradiated }\end{array}$ & $\begin{array}{l}0.37(0.04) \\
1.51(0.27)\end{array}$ & $\begin{array}{l}0.03(0.07) \\
1.23(0.32)\end{array}$ & $\begin{array}{l}1.17(0.41) \\
3.77(0.62)\end{array}$ & $\begin{array}{l}2.92(0.55) \\
6.55(1.99)\end{array}$ & $\begin{array}{l}2.35(1.57) \\
1.54(0.31)\end{array}$ \\
\hline I & $\begin{array}{l}\text { Non irrad. } \\
\text { Irradiated }\end{array}$ & $\begin{array}{l}0.43(0.27) \\
1.14(0.51)\end{array}$ & $\begin{array}{l}0.07(0.09) \\
1.38(0.86)\end{array}$ & $\begin{array}{l}0.42(0.16) \\
2.67(1.58)\end{array}$ & $\begin{array}{l}0.83(0.21) \\
2.48(1.24)\end{array}$ & $\begin{array}{l}2.10(0.99) \\
1.79(0.73)\end{array}$ \\
\hline$J$ & $\begin{array}{l}\text { Non irrad. } \\
\text { Irradiated }\end{array}$ & $\begin{array}{l}1.01(0.31) \\
1.82(0.52)\end{array}$ & $\begin{array}{l}0.29(0.09) \\
3.15(1.12)\end{array}$ & $\begin{array}{l}1.00(0.50) \\
5.37(1.87)\end{array}$ & $\begin{array}{l}1.79(0.53) \\
5.56(1.91)\end{array}$ & $\begin{array}{l}3.64(1.42) \\
3.33(1.09)\end{array}$ \\
\hline K & $\begin{array}{l}\text { Non irrad. } \\
\text { Irradiated }\end{array}$ & $\begin{array}{l}0.53(0.12) \\
1.43(0.77)\end{array}$ & $\begin{array}{c}\text { nd } \\
1.31(0.76)\end{array}$ & $\begin{array}{l}0.81(0.24) \\
2.88(1.61)\end{array}$ & $\begin{array}{l}1.61(0.39) \\
2.92(1.50)\end{array}$ & $\begin{array}{l}2.14(0.64) \\
2.18(0.82)\end{array}$ \\
\hline $\mathrm{L}$ & $\begin{array}{l}\text { Non irrad. } \\
\text { Irradiated }\end{array}$ & $\begin{array}{l}0.39(0.09) \\
2.10(0.10)\end{array}$ & $\begin{array}{c}\text { nd } \\
1.57(0.14)\end{array}$ & $\begin{array}{l}0.69(0.11) \\
3.24(0.24)\end{array}$ & $\begin{array}{l}1.07(0.40) \\
2.44(0.40)\end{array}$ & $\begin{array}{l}2.13(1.29) \\
1.95(0.86)\end{array}$ \\
\hline
\end{tabular}

release of bioavailable nitrogen from humic compounds in surface waters (Bushaw et al. 1996). One explanation for the lack of an observable photochemical stimulation of growth under nitrogen limitation in our study could be that an existing photoproduction of bioavailable DON from humic substances, as suggested by Bushaw et al. (1996), could be masked by a rather high initial amount of bioavailable nitrogen compounds in our experiment. It should be emphasized that the full water DON used in our study consists of compounds other than the isolated humic sub- stances used in the bioassay experiment presented in the study of Bushaw et al. (1996). Furthermore, our experimental results do not exclude the possible existence of a reversible photochemical release of bioavailable LMW nitrogen compounds (e.g. ammonium) from HMW DOM. Still, our bioassay results imply that, if existing, the impact of such a photolytic production of LMW nitrogen compounds on bacterial growth yield would be minor under the studied conditions (Fig. 3A).

Reche et al. (1999) studied the separate and combined effects of nutrient additions $(N+P)$ and solar

Table 3. Correlation coefficients ( $\mathrm{r}$ ) between DOC concentration, fluorescence, light absorption at $365 \mathrm{~nm}$, carboxylic acid (CA) photoproduction, DIC photoproduction, bacterial cell yield, and cell yield enhancement (\%) in C-limited, non-irradiated cultures. $\mathrm{n}=12, \cdot \mathrm{p}<0.05, \cdots \mathrm{p}<0.005, \cdots \mathrm{p}<0.001$

\begin{tabular}{|c|c|c|c|c|c|c|}
\hline & DOC & Fluorescence & Absorbance 365 & CA production & DIC production & Bacterial yield \\
\hline Fluorescence & $0.88 \cdots$ & & & & & \\
\hline Absorbance 365 & $0.95 \cdots$ & $0.85^{\cdots}$ & & & & \\
\hline CA production & $0.90^{\cdots}$ & $0.69^{\circ}$ & $0.91 \cdots$ & & & \\
\hline DIC production & $0.87 \cdots$ & $0.64^{\circ}$ & $0.81 \cdots$ & $0.93 \cdots$ & & \\
\hline Bacterial yield & $0.61^{\bullet}$ & $0.80^{\circ}$ & $0.69^{\circ}$ & 0.39 & 0.22 & \\
\hline Bacterial enhancement & $0.63^{\circ}$ & $0.68^{\circ}$ & $0.63^{\circ}$ & 0.53 & 0.54 & $0.71^{\circ}$ \\
\hline
\end{tabular}


irradiation on bacterial growth yield in humic surface water. Their experiments did not address the question of whether or not the amount of bioavailable nutrients was influenced by irradiation, but did show that bacterial growth yield was limited by nutrients irrespective of irradiation treatment. Furthermore, they showed that the bacterial growth efficiency was positively influenced by both irradiation and nutrient additions in their cultures. We did not observe any significant effects of irradiation on growth efficiency, but it should be noted that Reche et al. (1999) also include direct effects of radiation on bacteria, which could influence this parameter.

Between 4.4 and $27 \%$ of the total DOC appeared to be directly utilized by bacteria in our bioassay cultures. The relative size of this bioavailable fraction is in agreement with previous observations from various aquatic systems with a dominant input of allochthonous carbon (Tranvik 1988, Wikner et al. 1999). In general, bulk DOM quality was similar in water from the different sampling stations, except for the groundwater obtained from the mainly inorganic sandy soil (Stn A). This water had both a low total DOC, and a low DOC-specific absorptivity and humic substance fluorescence, as well as a very low DOC to DON ratio. These chemical differences in DOM were also reflected in a high bacterial growth yield under nitrogen-limited conditions. These results indicate the presence of a substantial fraction of labile, nitrogen-containing DOM of high substrate quality in the water (e.g. amino acids).

\section{Carboxylic acid photoproduction and bacterial growth enhancement}

Parallel to the photochemically induced increase in bacterial growth yield, there was a substantial abiotic production of LMW organic acids. Concentrations of oxalic, malonic, formic and acetic acids were markedly higher in sterile filtered and irradiated samples compared to non-irradiated controls. Several studies have demonstrated the existence of such a photochemical production of LMW carboxylic acids in humic surface waters or in aqueous solutions of humic or fulvic acids (Allard et al. 1994, Wetzel et al. 1995, Bertilsson \& Allard 1996). These substrates are directly available for heterotrophic bacterial utilization in surface waters (Hobbie \& Crawford 1969, Robinson et al. 1973, Vallino et al. 1996), and even though they have a rather low energy content per mole, photochemically produced carboxylic acids have been shown to act as important substrates for bacterioplankton growth and activity in a humic lake (Bertilsson \& Tranvik 1998). Thus, the photochemical increase in the pool of LMW carboxylic acids could partially explain the positive influence of irradiation on bacterial growth yield.

Assuming a $10 \%$ bacterial growth efficiency on the observed, photochemically produced carboxylic acids, these compounds could account for between 9.8 and $72 \%$ (average $33 \%$ ) of the photochemically induced stimulation of bacterial biomass yield observed in the cultures (Table 2). Thus, in combination with the weak correlation between the measured carboxylic acid photoproduction and the photoinduced stimulation of carbon-limited bacterial growth yield (Table 3), these results indicate the significance of other effects of irradiation on the organic substrate pool being available for bacterial utilization. Photoproduction of several LMW organic substrates such as pyruvate, glyoxylate, glutaraldehyde, formaldehyde, glyoxal and carbon monoxide has been demonstrated (reviewed by Moran \& Zepp 1997), but reported formation rates have generally been much lower than what was observed for the carboxylic acids measured in the present study.

\section{Coupling between carboxylic acid and DIC photoproduction}

Parallel to the production of LMW organic compounds, there was a decrease in the total DOC pool, measured as photooxidative DIC formation. Photooxidation has previously been identified as an important DOM removal mechanism in several freshwater systems (Granéli et al. 1996, Moran \& Zepp 1997). We observed a strong correlation between DIC and carboxylic acid photoproduction in the present study (Fig. 4, Table 3). Thus, the relative importance of these compounds as photoproducts does not appear to vary between the studied waters.

The parallel photooxidation of organic carbon and photoinduced increase in carbon-limited bacterial growth yield is not surprising per se, as it is in accordance with earlier findings (Lindell et al. 1995, Granéli et al. 1996). However, since this process results in a transformation of organic carbon into inorganic forms, the fraction being removed either has to be of low substrate quality, or could alternatively be masked by a parallel, larger increase in the pool of bioavailable carbon substrates, e.g. LMW carboxylic acids.

\section{CONCLUSIONS}

In conclusion, both bioassays and chemical analyses of LMW compounds showed that a photochemically induced production of bioavailable carbon occurred in water from stations along a wide transect in a boreal watershed. No corresponding increase in the bioavail- 
ability of nitrogen could be observed. Therefore, we suggest that there was a potential for a photochemically induced stimulation of bacterial growth yield due to alterations in the available carbon pool rather than in the available nitrogen pool. This response was found in all the studied water samples obtained from various sampling points in the river system. The results may therefore be relevant for a wide range of freshwaters with a high input of allochthonous carbon

Acknowledgements. This study was financed by grant I $3596-$ 322 from The Swedish Natural Research Council (NFR) for the global biogeochemistry project 'Aquatic transport and transformation of organic carbon-links in the carbon transfer from land to sea'. Financial support for the study was also provided by other grants from NFR, the Foundation for Strategic Environmental Research (MISTRA), and the foundation Oscar och Lili Lamms Minne. A.-K. Bergström, K. Bishop, B. Brämberg, B. Marcal de Faria, M. Jansson, A. Jonsson, and S. Köhler are acknowledged for participation in the laboratory work as well as for constructive comments and help during various stages of the work.

\section{LITERATURE CITED}

Allard B, Borén H, Pettersson C, Zhang G (1994) Degradation of humic substances by UV-irradiation. Environ Int 20: $97-101$

Andersson A, Hajdu S, Haecky P, Kuparinen J and Wikner J (1996) Succession and growth limitation of phytoplankton in the Gulf of Bothnia (Baltic Sea). Mar Biol 126:791-801

Azam F, Cho BC (1987) Bacterial utilization of organic matter in the sea. In: Fletcher M, Gray TRG, Jones JG (eds) Ecology of Microbial Communities Cambridge University Press, Cambridge, p 261-281

Bertilsson S, Allard B (1996) Sequential photochemical and microbial degradation of refractory dissolved organic matter in a humic freshwater system. Arch Hydrobiol/Adv Limnol 48:133-141

Bertilsson S, Tranvik LJ (1998) Photochemically produced carboxylic acids as substrates for freshwater bacterioplankton. Limnol Oceanogr 43(5):885-895

Bishop KH (1991) Episodic increase in stream acidity, catchment flow pathways and hydrograph separation. PhD thesis, Cambridge University, Cambridge

Blackburn N, Hagström $\AA$, Wikner $J$, Cuadros Hansson R, Bjørnsen PK (1998) Automatic counting, measurement, morphology, and growth rate estimates of bacteria in aquatic samples by image analysis. Appl Environ Microbiol 64(9):3246-3255

Bushaw KL, Zepp RG, Tarr MA, Schulz-Janders D, Bourbonniere RA, Hodson RE, Miller WL, Bronk DA, Moran MA (1996) Photochemical release of biologically available nitrogen from aquatic dissolved organic matter. Nature 381:404-407

Chaney A, Marbach EP (1962) Modified reagents for determination of urea and ammonia. Clin Chem 8:130-132

Dahlén J, Bertilsson S, and Pettersson C (1996) Effects of UVA irradiation on dissolved organic matter in humic surface waters. Environ Int 22(5):501-506

del Giorgio PA, Bird DF, Prairie YT, Planas D (1996) The flow cytometric determination of bacterial abundance in lake plankton with the green nucleic acid stain SYTO 13. Limnol Oceanogr 41:783-789 del Giorgio PA, Cole JJ, Cimbleris A (1997) Respiration rates in bacteria exceed phytoplankton production in unproductive systems. Nature, 385:148-151

Fenchel TM. Jorgensen BB (1977) Detritus food chains of aquatic ecosystems; the role of bacteria. Adv Microb Ecol $1: 1-58$

Geller A (1986) Comparison of mechanisms enhancing biodegradability of refractory lake water constituents. Limnol Oceanogr 31:755-764

Granéli W, Lindell MJ, Tranvik LJ (1996) Photooxidative $\mathrm{CO}_{2}$ production in lakes of different humic content. Limnol Oceanogr 41(4):698-706

Grasshoff K, Ehrhardt M, Kremling K (1983) Methods of seawater analysis. Verlag Chemie Weinheim, Weinheim

Hobbie JE, Crawford CS (1969) Respiration corrections for bacterial uptake of dissolved organic compounds in natural waters. Limnol Oceanogr 14:528-533

Hobbie JE, Daley RJ, Jasper S (1977) Use of nuclepore filters for counting bacteria by fluorescence microscopy. Appl Environ Microbiol 33:1225-1228

Ivarsson $\mathrm{H}$, Jansson $\mathrm{M}$ (1994) Temporal variations of organic carbon in the River Öre, Northern Sweden. Verh Int Verein Limnol 25:1522-1525

Kieber RJ, Zho X, Mopper K (1990) Formation of carbonyl compounds from UV-induced photodegradation of humic substances in natural waters: fate of rivering carbon in the sea. Limnol Oceanogr 35:1503-1515

Lancelot C, Billen G, and Mathot S (1989) Ecophysiology of phyto- and bacterioplankton growth in the Southern Ocean. In: S Caschetto (ed) Plankton ecology, Vol 1. Science Policy Office, Brussels, p 4-92

Lindell MJ, Granéli W, Tranvik LJ (1995) Enhanced bacterial growth in response to photochemical transformation of dissolved organic matter. Limnol Oceanogr 40(1):195-199

Loferer-Krößbacher M, Klima J, Psenner R (1998) Determination of bacterial cell dry mass by transmisson electron microscopy and densiometric image analysis. Appl Environ Microbiol 64(2):688-694

Malcolm RL, MacCarthy P (1992) Quantitative evaluation of XAD- 8 and XAD-4 resins used in tandem for removing organic solutes from water. Environ Int 18:597-607

Moran MA, Hodson RE (1990) Bacterial production on humic and nonhumic components of dissolved organic carbon. Limnol Oceanogr 35:1744-1756

Moran MA, Zepp RG (1997) Role of photoreactions in the formation of biologically labile compounds from dissolved organic matter. Limnol Oceanogr 42(6):1307-1316

Münster U, Einiö P, Nurminen J, Overbeck J (1992) Extracellular enzymes in a polyhumic lake: important regulators in detritus processing. Hydrobiologia 229:225-238

Peltzer ET, Fry B, Doering $\mathrm{PH}$, McKenna $\mathrm{JH}$, Norrman B, Zweifel UL (1996) A comparison of methods for the measurement of disolved organic carbon in natural waters. Mar Chem 54:85-96

Porter KG, Feig YS (1980) The use of DAPI for identifying and counting aquatic microflora. Limnol Oceanogr 25:943-948

Reche I, Pace ML, Cole JJ (1999) Interactions of photobleaching and inorganic nutrients in determining bacterial growth on colored dissolved organic carbon. Microb Ecol 36:270-280

Robinson GGC, Hendzel LL, Gillespie DC (1973) A relationship between heterotrophic utilization of organic acids and bacterial populations in West Blue Lake, Manitoba. Limnol Oceanogr 18:264-269

Simon M, Azam F (1989) Protein content and protein synthesis rates of planktonic marine bacteria. Mar Ecol Progr Ser 51:201-213 
Tranvik L (1988) Availability of dissolved organic carbon for planktonic bacteria in oligotrophic lakes of differing humic content. Microb Ecol 16:311-322

Tranvik L (1990) Bacterioplankton growth on different molecular weight fractions of dissolved organic carbon from humic and clear waters. Appl Environ Microbiol 56: $1672-1677$

Tranvik L (1998) Degradation of dissolved organic matter in humic waters by bacteria. In: Hessen DO, Tranvik LJ (eds) Aquatic humic substances-ecology and biogeochemistry. Springer, Berlin, p 259-283

Vallino JJ, Hopkinson CS, Hobbie J (1996) Modeling bacterial utilization of dissolved organic matter: optimization

Editorial responsibility: Karel Simek, Ceské Budẻjovice, Czech Republic replaces Monod growth kinetics. Limnol Oceanogr 41 . 1591-1609

Wetzel RG, Hatcher PG, Bianchi TS (1995) Natural photolysis by ultraviolet irradiance of recalcitrant dissolved organic matter to simple substrates for rapid bacterial metabolism. Limnol Oceanogr 40:1369-1380

Wikner J, Cuadros R, Jansson M (1999) Differences in consumption of allochthonous DOC under limnic and estuarine conditions in a watershed. Aquat Microb Ecol 17: 289-299

Zweifel UL, Norrman B, Hagström $\AA$ (1993) Consumption of dissolved organic carbon by marine bacteria and demand for inorganic nutrients. Mar Ecol Prog Ser 101:23-32

Submitted: October 26, 1998; Accepted: March 10, 1999 Proofs received from author(s): August 25, 1999 